\title{
Tumor-associated Endo180 requires stromal-derived LOX to promote metastatic prostate cancer cell migration on human ECM surfaces
}

\author{
Matthew P. Caley ${ }^{1,2} \cdot$ Helen King ${ }^{1,3} \cdot$ Neel Shah ${ }^{1,4,5} \cdot$ Kai Wang $^{6}$. \\ Mercedes Rodriguez-Teja $^{1,7} \cdot$ Julian H. Gronau ${ }^{1} \cdot$ Jonathan Waxman $^{1}$. \\ Justin Sturge ${ }^{1,6}$
}

Received: 26 June 2014/ Accepted: 2 November 2015/Published online: 13 November 2015

(C) The Author(s) 2015. This article is published with open access at Springerlink.com

\begin{abstract}
The diverse composition and structure of extracellular matrix (ECM) interfaces encountered by tumor cells at secondary tissue sites can influence metastatic progression. Extensive in vitro and in vivo data has confirmed that metastasizing tumor cells can adopt different migratory modes in response to their microenvironment. Here we present a model that uses human stromal cell-derived matrices to demonstrate that plasticity in tumor cell movement is controlled by the tumor-associated
\end{abstract}

Matthew P. Caley, Helen King and Neel Shah have contributed equally to this work.

Electronic supplementary material The online version of this article (doi:10.1007/s10585-015-9765-7) contains supplementary material, which is available to authorized users.

Justin Sturge

j.sturge@hull.ac.uk

1 Department of Surgery \& Cancer, Imperial College London, London W12 0NN, UK

2 Centre for Cutaneous Research, Blizard Institute, Barts \& The London School of Medicine \& Dentistry, Queen Mary University of London, London E1 2AT, UK

3 Division of Cancer Studies, King's College London, New Hunts House, Guys Campus, London SE1 1UL, UK

4 Human Oncology and Pathogenesis Program, Memorial Sloan-Kettering Cancer Center, New York, NY 10065, USA

5 Louis V. Gerstner, Jr. Graduate School of Biomedical Sciences, Memorial Sloan-Kettering Cancer Center, New York, NY 10065, USA

6 School of Biological, Biomedical \& Environmental Sciences, University of Hull, Cottingham Road, Hull HU6 7RX, UK

7 Departamento de Genética, Facultad de Medicina, Universidad de la República (UDELAR), Montevideo, Uruguay collagen receptor Endo180 (CD280, CLEC13E, KIAA0709, MRC2, TEM9, uPARAP) and the crosslinking of collagen fibers by stromal-derived lysyl oxidase (LOX). Human osteoblast-derived and fibroblast-derived ECM supported a rounded 'amoeboid-like' mode of cell migration and enhanced Endo180 expression in three prostate cancer cell lines (PC3, VCaP, DU145). Genetic silencing of Endo180 reverted PC3 cells from their rounded mode of migration towards a bipolar 'mesenchymal-like' mode of migration and blocked their translocation on human fibroblast-derived and osteoblast-derived matrices. The concomitant decrease in PC3 cell migration and increase in Endo180 expression induced by stromal LOX inhibition indicates that the Endo180-dependent rounded mode of prostate cancer cell migration requires ECM crosslinking. In conclusion, this study introduces a realistic in vitro model for the study of metastatic prostate cancer cell plasticity and pinpoints the cooperation between tumorassociated Endo180 and the stiff microenvironment imposed by stromal-derived LOX as a potential target for limiting metastatic progression in prostate cancer.

Keywords Bone - Cell migration - Collagen - Fibroblast . Osteoblast · Prostate cancer

$\begin{array}{ll}\text { Abbreviations } \\ \text { AGE } & \text { Advanced glycation end-product } \\ \text { BAPN } & \text { Beta-aminopropionitrile } \\ \text { BSA } & \text { Bovine serum albumin } \\ \text { CTLD } & \text { C-type lectin domain } \\ \text { DOCK10 } & \text { Dedicator of cytokinesis 10 } \\ \text { ECM } & \text { Extracellular matrix } \\ \text { EMT } & \text { Epithelial to mesenchymal transition } \\ \text { EphA2 } & \text { Ephrin type-A receptor 2 } \\ \text { FBS } & \text { Fetal bovine serum }\end{array}$




\section{FMNL2 Formin-like 2}

GAPDH Glyceraldehyde 3-phosphate dehydrogenase

GFP Green fluorescent protein

HRP Horse radish peroxidase

IFB Immnofluorescence buffer

LOX Lysyl oxidase

MBD Metastatic bone disease

MTT 3-(4,5-Dimethylthiazol-2-yl)-2,5-

diphenyltetrazolium bromide

MLC2 Myosin light chain-2

N-WASP Neuronal Wiskott-Aldrich syndrome protein

PAK2 p21 protein (Cdc42/Rac)-activated kinase 2

PBS Phosphate buffered saline

PDK1 Pyruvate dehydrogenase kinase, isozyme 1

RasGRF2 Ras protein-specific guanine nucleotidereleasing factor 2

ROCK Rho associated protein kinase

shSCN shEndo180 scrambled control

SOX2 SRY (sex determining region Y)-box 2

TGF $\beta_{1} \quad$ Transforming growth factor-beta-1

TGF $\beta_{1} \mathrm{R} \quad$ Transforming growth factor-beta-1 receptor

UPARAP Urokinase plasminogen activator receptor associated protein

\section{Introduction}

Metastatic bone disease (MBD) affects approximately 1 million advanced cancer patients per annum in the EU, USA and Japan; and estimates suggest that approximately one fifth of MBD cases result from advanced prostate cancer [1]. MBD is normally accompanied by the presence of additional metastatic lesions in visceral organs. However, in vitro experimental systems used to study putative metastatic targets tend to overlook the precise composition, organization and bioactivity of human bone and visceral tissues. The de novo extracellular matrix (ECM) produced by human trabecular bone osteoblasts is abundant in the minerals, proteins and growth factors found in normal human bone, which provides an accurate biomaterial to study therapeutic targets in the context of MBD [2-4]. Likewise, human fibroblast-derived ECM has been used to develop more realistic in vitro models of human cancer localized in visceral tissue in which its influence on therapeutic strategies can be considered $[5,6]$.

Tumor cells can adopt different modes of migration during metastasis. Three modes of tumor cell migration include grouped, bipolar and rounded, which respectively involve: (a) collective 'epithelioid-like' cell clusters directed by a leader cell; (b) 'mesenchymal-like' translocation of single cells coordinated by forward protrusion

and rear retraction of the plasma membrane; and (c) 'amoeboid-like' forward translocation of singular spheroidal cells [7, 8]. Tumor cells can switch back-andforth between different modes of migration in response to external and/or internal cues. This type of morphological plasticity is a feature of the epithelial-to-mesenchymal, mesenchymal-to-amoeboid and collective-to-amoeboid transitions that occur during tumor progression [9, 10]. The 'amoeboid-like' cell phenotype predominates at the invasive edge of high-grade tumors [11] and has been identified as an escape mechanism from some anti-invasive strategies [12]. Tumor cells engaged in this rounded mode of cell migration do not require focal adhesion turnover as they do for bipolar 'mesenchymal-like' migration [13]. Instead rounded cell migration is driven by the spatial localization of integrins and cytoskeletal regulators at the posterior plasma membrane $[14,15]$ and generation of RhoA and Rho kinase associated protein kinase (ROCK)-based actinomyosin contractile signals [16].

The type I transmembrane collagen receptor Endo180 (CD280, CLEC13E, KIAA0709, MRC2, TEM9, uPARAP) is as a strong prognostic indicator for prostate cancer survival $[17,18]$. Within this context Endo180 functions as a modulatory switch for epithelial-to-mesenchymal transition (EMT), and pro-invasive behavior in normal prostate epithelial cells triggered by increased crosslinking and stiffness of the basement membrane following its exposure to advanced glycation end-products (AGEs) [17, 18]. The pro-migratory and pro-invasive role of Endo180 involving the promotion of RhoA-ROCK-based actinomyosin contractility at the cell posterior [17-19] has been confirmed in a range of tumor and stromal cell types, both in vivo and in vitro, using ectopic over expression, genetic silencing, genetic ablation or targeted blockade of receptor function [17-30]. Given the expression of Endo180 observed in tumor cell foci in metastatic bone lesions [4], and increased levels of soluble Endo180 in the serum of patients with visceral and bone metastases [31], we hypothesized that Endo180 can regulate prostate cancer cell plasticity on the bone-like ECM derived from human osteoblasts and visceral tissue-like ECM derived from human fibroblasts.

Lysyl oxidase (LOX) is a copper-dependent amine oxidase that is produced by osteoblasts and fibroblasts to give tissue its structural support and mechanical stiffness by crosslinking the adjacent collagen fibers that they deposit as part of the ECM [32, 33]. LOX plays a fundamental role in metastasis [34-37], including the formation of the pre-metastatic lesions in bone that are colonized by circulating tumor cells and expand into occult osteolytic metastases [38]. Considering the positive cooperation between tumor-associated Endo180 and AGE-dependent crosslinking and stiffness of basement membrane matrix [18], we hypothesized that Endo180-dependent prostate 
cancer cell migration cooperates with LOX-dependent crosslinking of the ECM derived from human osteoblasts and fibroblasts.

\section{Materials and methods}

\section{Cells and cell culture}

For osteoblast isolation approximately fifty post-operative human trabecular bone chips of $1-2 \mathrm{~mm}^{2}$ were washed thoroughly in PBS to remove hematopoietic cells and incubated for $2 \mathrm{~h}$ at $37{ }^{\circ} \mathrm{C}$ in $10 \mathrm{ml}$ of $1.2 \mathrm{mg} / \mathrm{ml}$ type IV collagenase diluted in DMEM (Invitrogen Ltd. Paisley, UK). Supernatants containing digested cellular components $\left(>10^{7}\right.$ cells) were harvested and cultured at $37{ }^{\circ} \mathrm{C}$ in $5 \%$ $\mathrm{CO}_{2}$ in a 1:1 mix of DMEM and F-12 medium (Invitrogen Ltd.) supplemented with $10 \%$ v/v FBS (First Link UK Ltd., Birmingham, UK), 2 mM L-glutamine, $100 \mathrm{U} / \mathrm{ml}$ penicillin, $100 \mathrm{mg} / \mathrm{ml}$ streptomycin and $0.25 \mathrm{mg} / \mathrm{ml}$ amphotericin B (Invitrogen Ltd.). Primary human osteoblasts and HCA2-hTERT human fibroblasts were maintained in DMEM $+10 \%$ v/v FCS, $1 \mathrm{mM}$ penicillin/ streptomycin and $2 \mathrm{mM}$ L-glutamine.

PC3, DU145 and VCAP cells were maintained in RPMI medium (Invitrogen Ltd.) $+10 \%$ v/v FBS, $1 \mathrm{mM}$ penicillin/streptomycin and $2 \mathrm{mM} \mathrm{L-glutamine.} \mathrm{Endo180}$ knockdown and control cells were generated by transfection (Qiagen Superfect) of PC3 cells with the shRNA vector pRNATin-H1.2/Hygro containing coral GFP (Antibodies-Online $\mathrm{GmbH}$, Aachen, Germany) and shEndo180 or non-targeting shEndo180 scrambled control (shSCN) sequence inserts $[26,39]$ that were evaluated previously to rule out any off-target effects on other pro-migratory and pro-invasive proteins [17, 19]. Transfected cells were selected in fully supplemented DMEM containing hygromycin-B $(20 \mu \mathrm{g} / \mathrm{ml})$ (Santa Cruz Biotechnology Inc., Heidelberg, Germany, UK). PC3 cells were transfected with the pcDNA3-Endo180 or empty pcDNA3 vector using lipofectamine and selected with G418 $(0.5 \mathrm{mg} / \mathrm{ml})$, as previously described [26, 39].

\section{Matrix preparation and analysis}

Rat type I collagen derived from rat tails was commercially sourced (\#354236, BD Biosciences, Oxford, UK) and used at a concentration of $50 \mu \mathrm{g} / \mathrm{ml}$ in $0.02 \mathrm{M}$ glacial acetic acid to coat wells following the manufacturers instructions. For human cell-derived ECM production HCA2 fibroblasts and primary human trabecular bone osteoblasts were seeded at a density of $1.5 \times 10^{4}$ cells per well in 96-well plates (\#CLS3595, Corning ${ }^{\circledR}$ Costar $^{\circledR}$ ). Confluent cultures of HCA2 fibroblasts were stimulated with $2 \mathrm{mM}$ ascorbate to induce the production of native ECM. Confluent cultures of primary human trabecular bone osteoblasts were stimulated with $100 \mu \mathrm{M}$ ascorbate, $10 \mathrm{nM}$ dexamethasone and $10 \mathrm{mM}$ $\beta$-glycerophosphate to induce mineralized ECM production as previously described [2, 4]. Stimulation media were replaced every 2 days. After 10 days cells were washed with PBS $(3 \times 5 \mathrm{~min})$ and removed by three successive freeze-thaw cycles (in PBS) and incubation in $1 \% \mathrm{w} / \mathrm{v}$ sodium deoxycholate for $5 \mathrm{~min}$. Resulting decellularized matrices were washed with PBS $(5 \times 5 \mathrm{~min})$ before use. Mineralization was determined by von Kossa staining (5\% w/v silver nitrate), as previously described [4].

BAPN (0.1-1.0 mM) was included in stimulation media of fibroblasts and osteoblasts during the 10-day period of matrix generation to inhibit LOX-dependent type I collagen fiber crosslinking. After 10 days the matrices generated in the presence of BAPN were decellularized. The inhibitory effect of BAPN on collagen crosslinking in fibroblast-derived ECM and osteoblast-derived ECM was ascertained by adapting a previously described method [37]. In brief, decellularized ECM derived from fibroblasts and osteoblasts (untreated or treated with BAPN) were immunostained with rabbit anti-human type I collagen polyclonal antibody (R1038X, Acris Antibodies $\mathrm{GmbH}$, Herford, Germany) and secondary anti-rabbit Alexa Fluor 488-conjugated IgG (Invitrogen Ltd.). Images of the type I collagen fibers present in fibroblast-derived ECM and osteoblast-derived ECM were acquired using Image Xpress $^{\text {MICRO }}$ (IXM) (Molecular Devices UK Ltd., Wokingham UK) [4]. The curvature ratio (defined as $x / y$, where $x=$ the total length of each fiber and $y=$ the linear distance between the start and end of each fiber) was calculated using Image $\mathbf{J}$ software (arbitrary units) in images of type I collagen fibers. The same images were processed using Metamorph ${ }^{\circledR}$ software (Molecular Devices UK Ltd.) to calculate integrated fluorescent signal intensity per unit area $\left(\mu \mathrm{m}^{2}\right)$ using a modification of a protocol used to calculate the integrated fluorescent signal intensity of type I collagen fibers per cell [4].

\section{Cell morphology and migration assays}

Cells were seeded at a density of $2 \times 10^{3}$ cells per well on plastic, type I collagen, fibroblast-derived ECM and osteoblast-derived ECM in 96-well Optilux Black/Clear Bottom plates (\#734-0395, VWR International Ltd., Lutterworth, UK) and allowed to adhere prior to image acquisition at a rate of 1 frame every $30 \mathrm{~min}$ for $24 \mathrm{~h}$ using IXM set to live cell imaging mode $\left(5 \% \mathrm{v} / \mathrm{v} \mathrm{CO}_{2}\right.$ at $\left.37{ }^{\circ} \mathrm{C}\right)$. Segmented images were used to manually score the number of cells that were undergoing 'grouped' versus 'singular' cell migration at time zero $(0 \mathrm{~h})$ and at each 6 -h time point of for the 24-h experimental time frame. In the case of 'singular' cell 
Table 1 Criteria used for scoring different modes of prostate cancer cell migration

\begin{tabular}{|c|c|c|}
\hline Migratory mode & Cellular morphology observed during translocation & $\begin{array}{l}\text { Criteria used to define the predominant } \\
\text { mode of migration }\end{array}$ \\
\hline Grouped & $\begin{array}{l}\text { Epithelioid; as part of a moving cell cluster or participation in frequent } \\
\text { interactions with adjacent cells }\end{array}$ & $\begin{array}{l}>80 \% \text { cells display epithelioid } \\
\text { morphology during translocation }\end{array}$ \\
\hline Singular, bipolar & $\begin{array}{l}\text { Mesenchymal; movement as elongated singular cell with defined leading } \\
\text { edge and retraction of trailing uropod }\end{array}$ & Rounded/bipolar ratio $<1.0$ \\
\hline Singular, rounded & Amoeboid; movement as spheroid without a retracting uropod & Rounded/bipolar ratio $>1.0$ \\
\hline Singular, mixed & Equal numbers of cells with mesenchymal and amoeboid morphologies & Rounded/bipolar ratio $=1.0$ \\
\hline
\end{tabular}

migration cells were scored according to a bipolar versus rounded mode of cell migration. The predominant mode of cell migration was classified according to the criteria presented in Table 1 . The $\%$ of cells with each phenotype was then used to calculate the rounded/bipolar ratio at time zero $(0 \mathrm{~h})$ and at each $6-\mathrm{h}$ time point of the $24-\mathrm{h}$ experimental time frame. The average cell velocities $(\mu \mathrm{m} / \mathrm{h})$ were calculated from the cell trajectories generated from manual cell tracking and post analysis (Metamorph ${ }^{\circledR}$ software). For all conditions tested the tracks from $\geq 100$ cells were used to calculate the average cell velocities.

\section{Flow cytometry}

Cells were trypsinized and fixed in $4 \% \mathrm{w} / \mathrm{v}$ paraformaldehyde (10 min), blocked and permeabilized in immunofluorescence buffer (IFB: $4 \% \mathrm{w} / \mathrm{v} \mathrm{BSA}$ and $1 \% \mathrm{v} / \mathrm{v}$ FBS) containing $0.2 \% \mathrm{w} / \mathrm{v}$ saponin. Cells were pelleted and incubated with anti-human Endo180 primary monoclonal antibody (A5/158, E1/183 or 39.10) diluted in IFB (1 h), washed in IFB $(3 \times 5 \mathrm{~min})$, incubated with Alexa Fluor555 conjugated secondary antibody diluted in IFB $(1 \mathrm{~h})$ and washed IFB $(3 \times 5 \mathrm{~min})$. Cells were pelleted, resuspended in PBS and assessed by flow cytometry (BD FACS Canto, $\mathrm{BD}$, Oxford, UK). Gating was performed with unstained cells and cells stained with isotype matched IgG.

\section{Immunoblot analysis}

Protein concentrations in whole cell lysates were determined using a Pierce BCA protein assay kit. Equal amounts of protein were resolved by SDS-PAGE using $7 \% \mathrm{w} / \mathrm{v}$ polyacrylamide gels and electroblotted onto PVDF membranes, which were incubated at room temperature in blocking buffer (PBS $+5 \%$ w/v BSA) $(1 \mathrm{~h})$ then primary antibody (anti-Endo180 A5/158 mAb; anti-GAPDH) diluted in blocking buffer at $4{ }^{\circ} \mathrm{C}(16 \mathrm{~h})$. After washes in PBS $+0.1 \% \mathrm{v} / \mathrm{v}$ Tween ${ }^{\circledR}-20$ (PBS-T) $(5 \times 5$ min $)$ blots were incubated in HRP-conjugated goat anti-mouse or goat anti-rabbit IgG diluted in blocking buffer $(1 \mathrm{~h})$. Blots were washed in PBS-T $(5 \times 5 \mathrm{~min})$ prior to visualization of immunoreactive bands using chemiluminescence.

\section{Cell adhesion assay}

Cell adhesion could not be measured using crystal violet because the fibroblast-derived and osteoblast-derived ECM retained the stain. Instead, cells were seeded at a density of $1.5 \times 10^{4}$ per well of a 96-well plate onto test substrata and incubated for $1 \mathrm{~h}$ before washing in PBS and addition of culture medium containing CellTiter-Glo ${ }^{\circledR}$ buffer (Promega, UK) at a ratio of 1:1 and final volume of $200 \mu \mathrm{l}$. Plates were mixed vigorously for $2 \mathrm{~min}$ to induce cell lysis and the contents of each well transferred to opaque 96-well plates (Corning ${ }^{\circledR}$ Costar $^{\circledR}$; Z37 185-8; Sigma Aldrich Ltd., Poole, UK). Luminescence was measured on a PHERAstarPlus plate reader (BMG LabTech, Aylesbury, UK).

\section{MTT cell proliferation assay}

$1.2 \times 10^{4}$ cells per well were seeded onto test substrata in 24-well plates and incubated for $48 \mathrm{~h} .5 \mathrm{mg} / \mathrm{ml}$ MTT was added and cells incubated for $3.5 \mathrm{~h}$ at $37{ }^{\circ} \mathrm{C}$. Media was removed and $300 \mu \mathrm{l}$ of extraction buffer $(0.5 \mathrm{M}$ dimethylformamide; $20 \% \mathrm{w} / \mathrm{v}$ SDS) added per well followed by incubation for $2 \mathrm{~h}$. $100 \mu \mathrm{l}$ of buffer was transferred per well to a 96-well plate. Absorbance $(570 \mathrm{~nm})$ was measured using a Sunrise plate reader (Labtech International Ltd., Ringmer, UK).

\section{Statistical analysis}

Student's $t$ test was performed using SPSS 15.0 software; $\mathrm{p}<0.05$ was considered significant.

\section{Results}

\section{Generation of human stromal cell-derived ECM surfaces with LOX-dependent cross links}

ECM generation was induced in confluent monolayers of primary human trabecular bone-derived osteoblasts isolated from post-operative human trabecular bone and human HCA2 dermal fibroblasts. After 10 days 
immunofluorescent staining of type I collagen fibers was performed on decellularized osteoblast-derived ECM (Fig. 1a) and decellularized fibroblast-derived ECM (Fig. 1b). Image analysis revealed that inhibition of collagen crosslinking with the LOX inhibitor BAPN did not affect the total levels of type I collagen deposition by human osteoblasts (Fig. 1c) or HCA2 fibroblasts (Fig. 1d) but induced a significant increase in the curvature ratio of the collagen fibers in both types of matrices (Fig. 1e, f). Von Kossa staining of osteoblast-derived ECM indicated that BAPN treatment does not affect mineralization (Fig. 1g). These results confirm that human osteoblastderived ECM and human fibroblast-derived ECM both require LOX to maintain their organized structure, thus providing two physiologically relevant substrata for studying how tumor-associated Endo180 modulates the plasticity of prostate cancer cell migration in the presence and absence of LOX-dependent collagen crosslinking.

\section{Rounded metastatic prostate cancer cell migration is favored on human bone matrix}

Three prostate cancer cell lines were included in the study: PC3 and VCaP that originate from bone metastatic lesions located in the lumbar vertebra [40, 41] and DU145 that originate from a soft tissue metastatic lesion in the parieto-

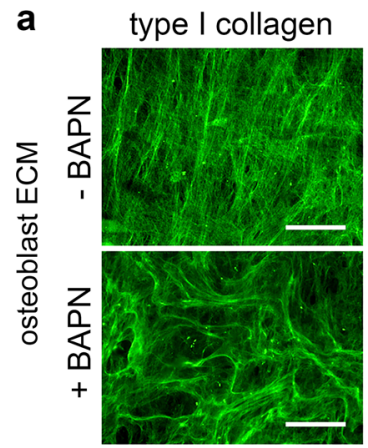

b
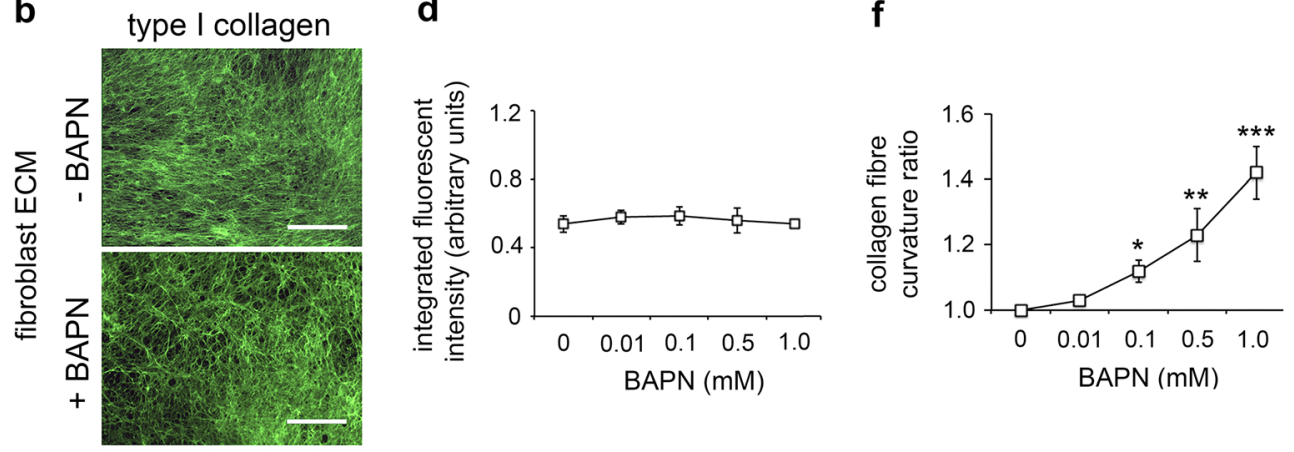

e

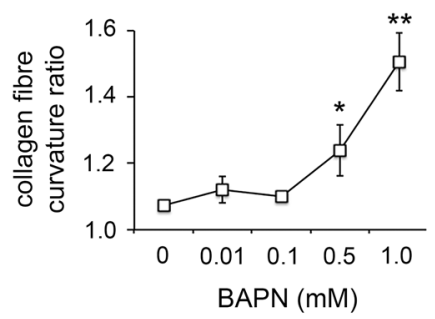

f g

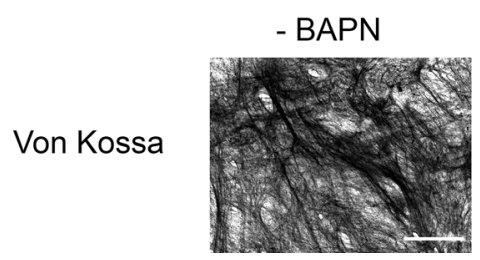

d
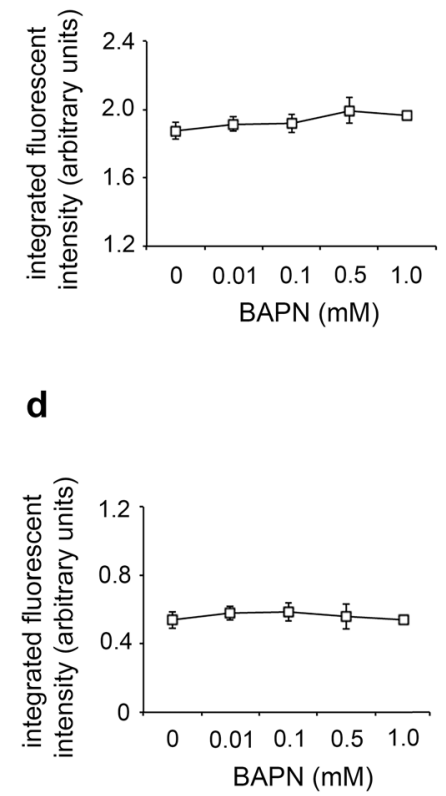

osteoblast ECM

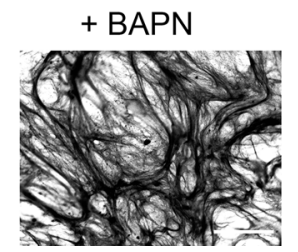

Fig. 1 LOX inhibition increases type I collagen fiber curvature in matrices produced by human stromal cells. a, b Immunofluorescent images of type I collagen fibers produced by primary human trabecular bone osteoblasts (a) and human HCA2 dermal fibroblasts (b) in the absence (-BAPN) or presence (+BAPN) of LOX inhibitor (1 mM), scale bar $=50 \mu \mathrm{m}$. c, d Relative levels of total type I collagen deposited by osteoblasts (c) and fibroblasts (d) in the absence (-) or presence of BAPN $(0.01-1 \mathrm{mM}$ ) (average \pm s.d. of integrated fluorescent intensity of immunostaining per $\mu \mathrm{m}^{2}$ ). e, f Collagen fiber curvature ratio in the matrices deposited by osteoblasts (e) and fibroblasts (f) in the absence (-) or presence of BAPN (0.01-1 mM); 20 collagen fibers measured for each condition in duplicate. e, f Average \pm s.d. values for three individual experiments, within which each experimental condition in duplicate, are shown; significant differences compared to control (no BAPN treatment $)$ are indicated $(* \mathrm{p}<0.05, \quad * * \mathrm{p}<0.001 \quad$ and $* * * \mathrm{p}<0.0003)$. g Von Kossa staining of osteoblast derived ECM generated in the absence $(-\mathrm{BAPN})$ or presence (+BAPN) of LOX inhibitor $(1 \mathrm{mM})$, scale bar $=50 \mu \mathrm{m}$ 
Fig. 2 Human stromal cellderived surfaces promote plasticity of movement in metastatic prostate cancer cells. a Stills extracted from Videos

1-12 in Online Resources 1-12 of PC3, $\mathrm{VCaP}$ and DU145 migrating on tissue culture plastic, commercial rat-tail type I collagen and native ECM generated by human HCA2 dermal fibroblasts (fibroblast ECM) and primary human trabecular bone osteoblasts (osteoblast ECM); scale $b a r=50 \mu \mathrm{m}$. b, c The percentages of $\mathrm{VCaP}$ cells

(b) and DU145 cells

(c) participating in grouped and singular modes of cell migration on the four substrata. d The rounded:bipolar ratios for singular PC3, VCaP and DU145 cells migrating on the four substrata; significant increases compared to type I collagen $(* \mathrm{p}<0.01)$ and fibroblast ECM $\left({ }^{+} \mathrm{p}<0.01\right)$ are indicated. $\mathbf{b}-$ d Average \pm s.d. values for three individual experiments, within which each experimental condition was tested in quadruplicate, are shown a

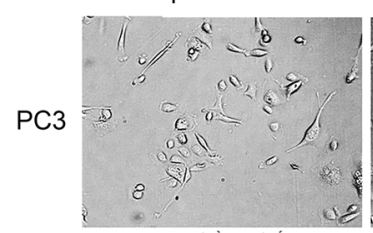

collagen

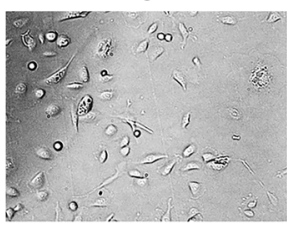

fibroblast ECM

osteoblast ECM
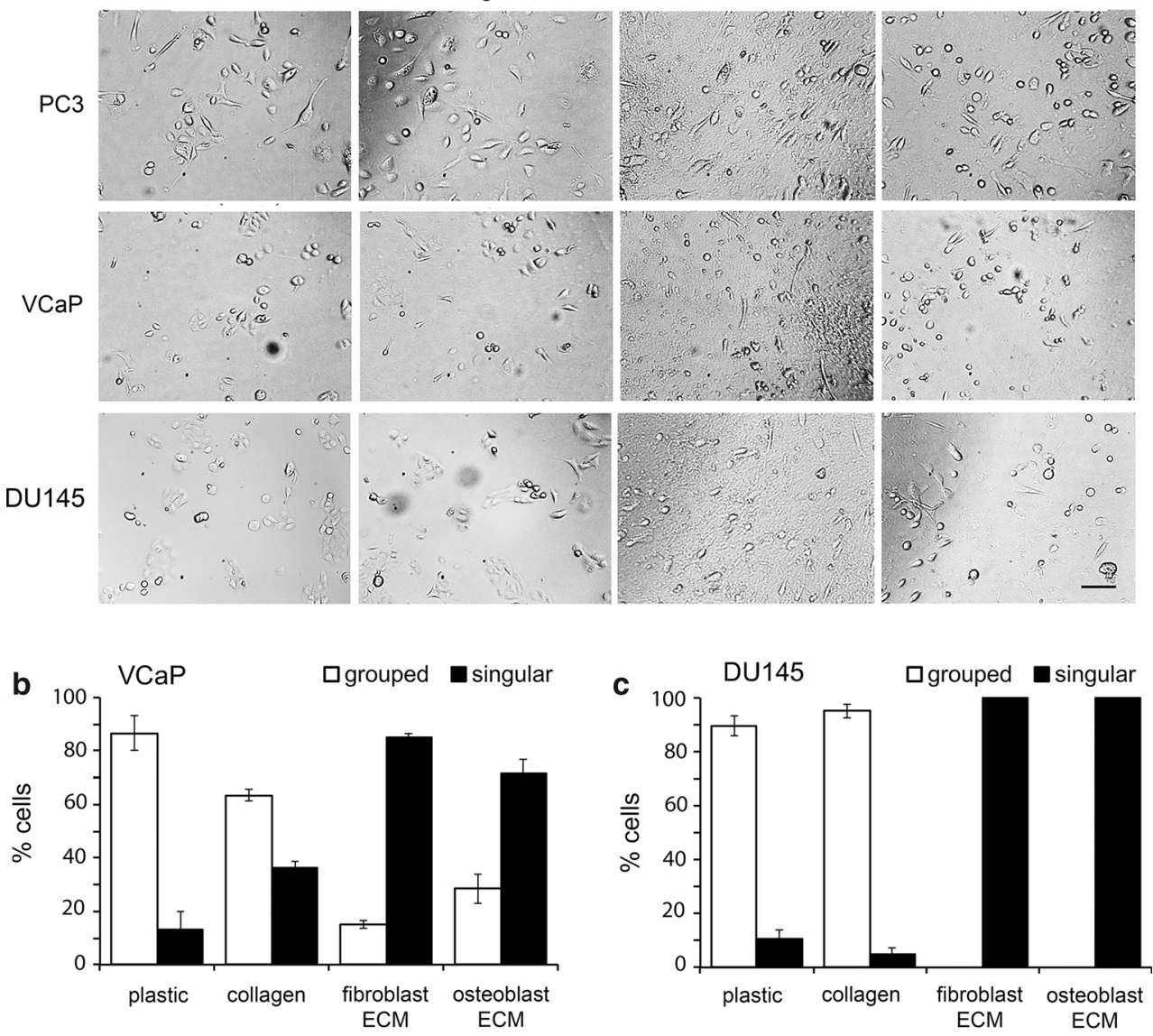

d

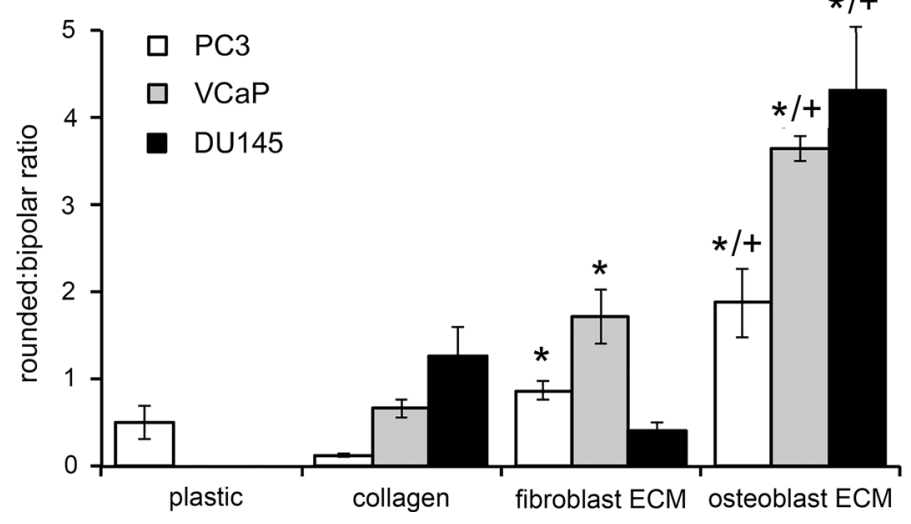

occipital fissure of the cerebrum [42]. Time-lapse video microscopy was used to compare their migratory behavior on standard tissue culture plastic, commercial type I collagen, fibroblast-derived ECM and osteoblast-derived ECM, as seen in the videos (Online Resources 1-12) and corresponding video stills (Fig. 2a). All movies were scrutinized and the observed mode of migration for each cell in the field of view was scored according to the criteria presented in Table 1. In the case of the two epithelioid-like cell lines, VCaP and DU145, the proportion of cells engaged in grouped and singular modes of cell migration were calculated (Fig. 2b, c). Under all other experimental conditions $>20 \%$ of cells adopted a singular migratory mode, which was considered sufficient for the rounded/bipolar ratio of cell migratory mode to be calculated (Fig. 2d).

PC3 and VCaP cells, but not DU145 cells, transitioned towards singular and bipolar modes of migration on collagen in comparison to tissue culture plastic (Fig. 2b-d). On the other hand, fibroblast-derived ECM supported singular mixed bipolar/rounded modes of migration for PC3 cells, a singular rounded mode of migration for $\mathrm{VCaP}$ cells and a singular bipolar mode migration for DU145 cells (Fig. 2d). 

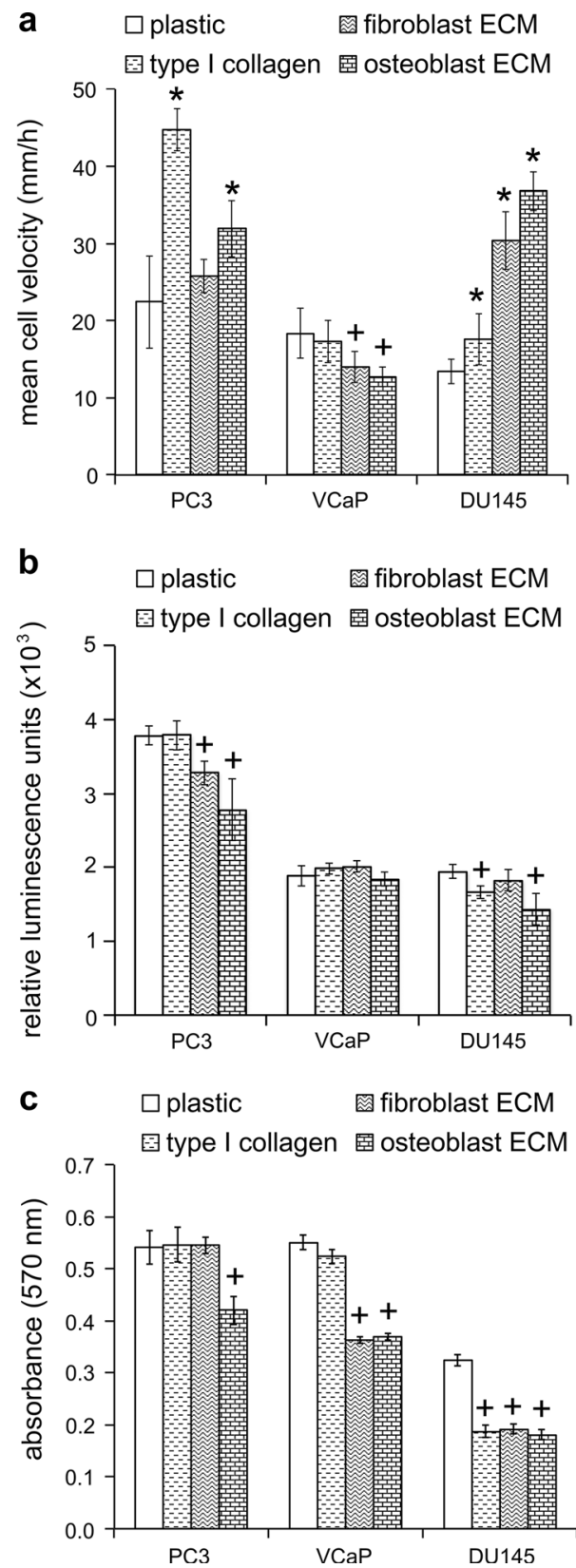

Fig. 3 The migration, adhesion and proliferation rates of metastatic prostate cancer cells are differentially modulated on human stromal cell-derived ECM surfaces. a-c The migratory velocities $(\mu \mathrm{m} / \mathrm{h})$ over a $24 \mathrm{~h}$ time-frame (a), adhesion levels at $1 \mathrm{~h}$ (b) proliferation rates at $48 \mathrm{~h}$ (c) of PC3, VCaP and DU145 cells cultured on tissue culture plastic (plastic), rat-tail type I collagen (type I collagen), human HCA2 fibroblast-derived ECM (fibroblast ECM) and human trabecular bone osteoblast-derived ECM (osteoblast ECM). a-c Average \pm s.d. values for three individual experiments, within which each experimental condition was tested in quadruplicate, are shown. Significant increases $(* p<0.05)$ and decreases $\left({ }^{+} p<0.05\right)$ compared to plastic are indicated

Moreover, for all three cell-types the predominant mode of migration on osteoblast-derived ECM was singular and rounded (Fig. 2d). The rounded migration of PC3 and
DU145 cells on osteoblast-derived ECM was associated with a high velocity (Fig. 3a), a decreased adhesion (Fig. 3b) and decreased proliferation (Fig. 3c) when compared to the same parameters on plastic. In contrast, the rounded migratory mode of VCaP cells that predominated on both fibroblastderived and osteoblast-derived ECM was associated with a low velocity (Fig. 3a), no change in adhesion (Fig. 3b) and decreased proliferation (Fig. 3c) when compared to plastic. These data confirm that metastatic prostate cancer cells display plasticity in their mode of migration on human stromal cell-derived ECM.

\section{Endo180 is upregulated in metastatic prostate cancer cells in contact with human ECM}

Flow cytometry analysis using three anti-human Endo180 monoclonal antibodies (A5/158, E1/183, 39.10) confirmed that the receptor is expressed in $\mathrm{PC} 3, \mathrm{VCaP}$ and DU145 cells (Fig. 4a). The differential Endo180 staining profiles of the three antibodies may reflect differences in their epitope engagement and/or masking by ligand binding and/or the open-closed conformational state of the receptor, as a molecular mechanism postulated in our two recent studies $[17,18]$. Immunofluorescent staining analysis confirmed that Endo180 levels were significantly increased in DU145 cells, parental PC 3 cells and PC 3 cells that overexpress Endo180 (PC3-Endo180) cultured on human osteoblast-derived ECM and fibroblast-derived ECM (Fig. 4b, c). Endo180 appeared to cluster in 'hot-spots' in cells with a rounded phenotype (Fig. 4b). Immunoblot analysis and densitometry confirmed that Endo180 was also upregulated in $\mathrm{VCaP}$ cells cultured for 6-24 h on human osteoblast-derived ECM (up to 4-fold) and fibroblast-derived ECM (up to 9-fold) (Fig. 4d, e); immunoblotting results were similar for PC3 and DU145 cells (Supplementary Data Figure S1). The decrease in Endo180 levels at $48 \mathrm{~h}$ could be due to the depletion of factors that promote Endo180 expression in the bone microenvironment, such as transforming growth factor-beta$1\left(\mathrm{TGF} \beta_{1}\right)$. These findings are in accordance with results obtained using co-cultures of human trabecular bonederived osteoblasts and DU145 or PC3 cells [4], Endo180 immunostaining of tumor cell foci in MBD [4] and its raised levels in the serum of patients with osseous and/or visceral metastases [31].

\section{Endo180 is required for rounded prostate cancer cell migration on human stromal ECM surfaces}

To test the hypothesis that Endo180 contributes to the plasticity of prostate cancer cell migration, PC3 cells were transfected with a scrambled control shRNA vector (PC3shSCN) or targeted Endo180 shRNA vector (PC3-shEndo180) (Fig. 5a), which contained a previously validated 

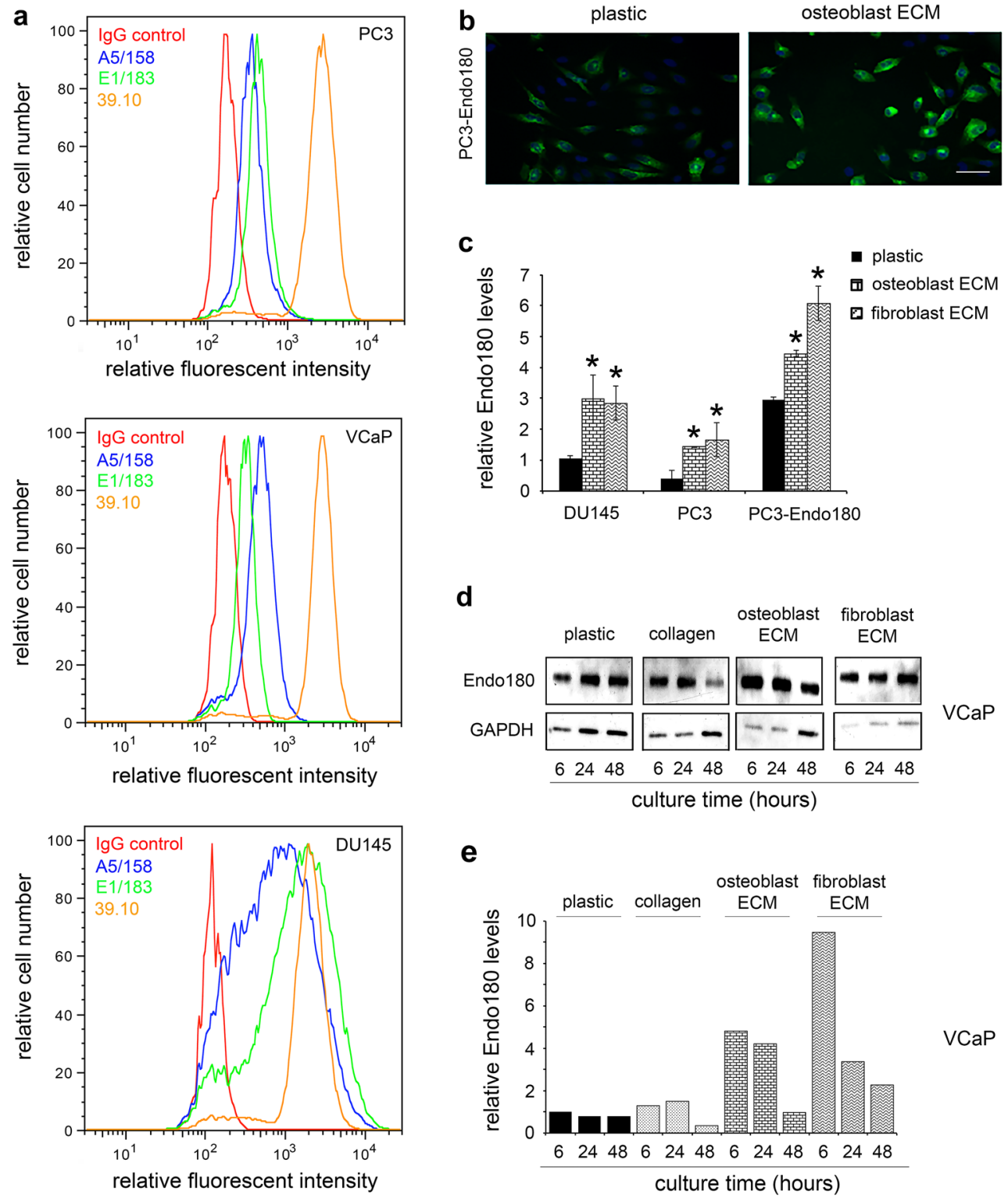

e

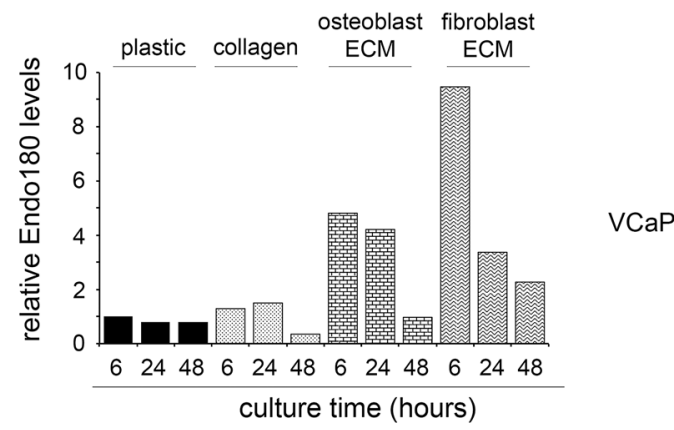

Fig. 4 Endo180 is upregulated in metastatic prostate cancer cells cultured on human stromal cell-derived ECM surfaces. a Flow cytometry analysis of PC3, VCaP and DU145 cells using three antihuman Endo180 monoclonal antibodies (A5/158, E1/183, 39.10). b Immunofluorescent staining of Endo180 (A5/158 mAb) in PC3Endo180 cells cultured on plastic and ECM generated by primary human trabecular bone osteoblasts (osteoblast ECM); scale bar $=50 \mu \mathrm{m}$. c Relative levels of Endo180 expression (integrated fluorescent intensity; A5/158 mAb immunostaining) in PC3, PC3Endo180 and DU145 cells cultured on tissue culture plastic (plastic)

siRNA oligonucleotide sequence [17, 19, 23, 24, 26, 27, 30] and was highly effective at silencing Endo180 (Fig. 5b, c). PC3-shSCN cells displayed a predominantly bipolar migratory mode on fibroblast-derived ECM and a predominantly rounded migratory mode on osteoblast-derived ECM, as seen in time-lapse videos (Online Resources 13 and 14) and corresponding frames (Fig. 5d, e). PC3-

and ECM generated by primary human trabecular bone osteoblasts (osteoblast ECM) and human HCA2 dermal fibroblasts (fibroblast ECM); average \pm s.d. values for three individual experiments, within which each experimental condition was tested in quadruplicate, are shown; significant differences compared to plastic are indicated (*p < 0.05). d Immunoblot shows Endo180 expression (A5/158 $\mathrm{mAb}$ ) in $\mathrm{VCaP}$ cells cultured on plastic, rat-tail type I collagen (collagen), osteoblast ECM and fibroblast ECM for 6, 24 and $48 \mathrm{~h}$ (GAPDH $=$ loading control). e Relative levels of Endo180 expression in $(\mathbf{d})$ quantified using densitometry $(\mathrm{n}=1)$

shEndo180 cells displayed a significant transition towards a bipolar morphology on both fibroblast-derived ECM and osteoblast-derived ECM, as seen in videos (Online Resources 16 and 17) and corresponding frames (Fig. 5d, e). Moreover, the rounded-to-bipolar transition that resulted from Endo180 silencing was accompanied by a dramatic reduction in cell velocity (Fig. 5f) associated with 

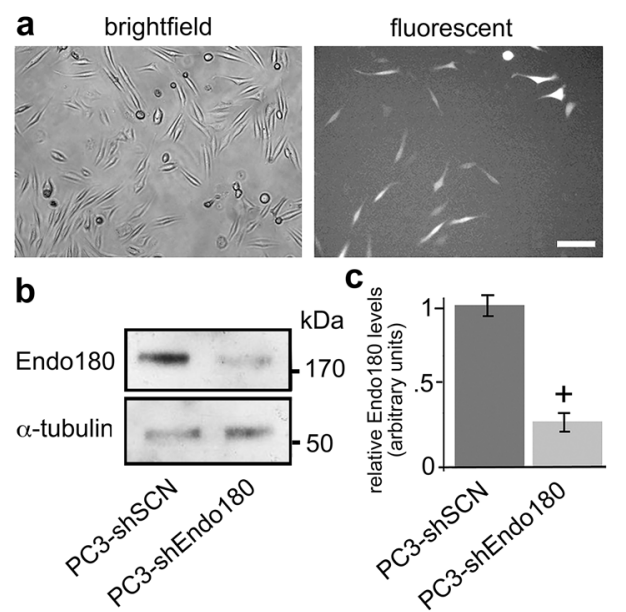

C.
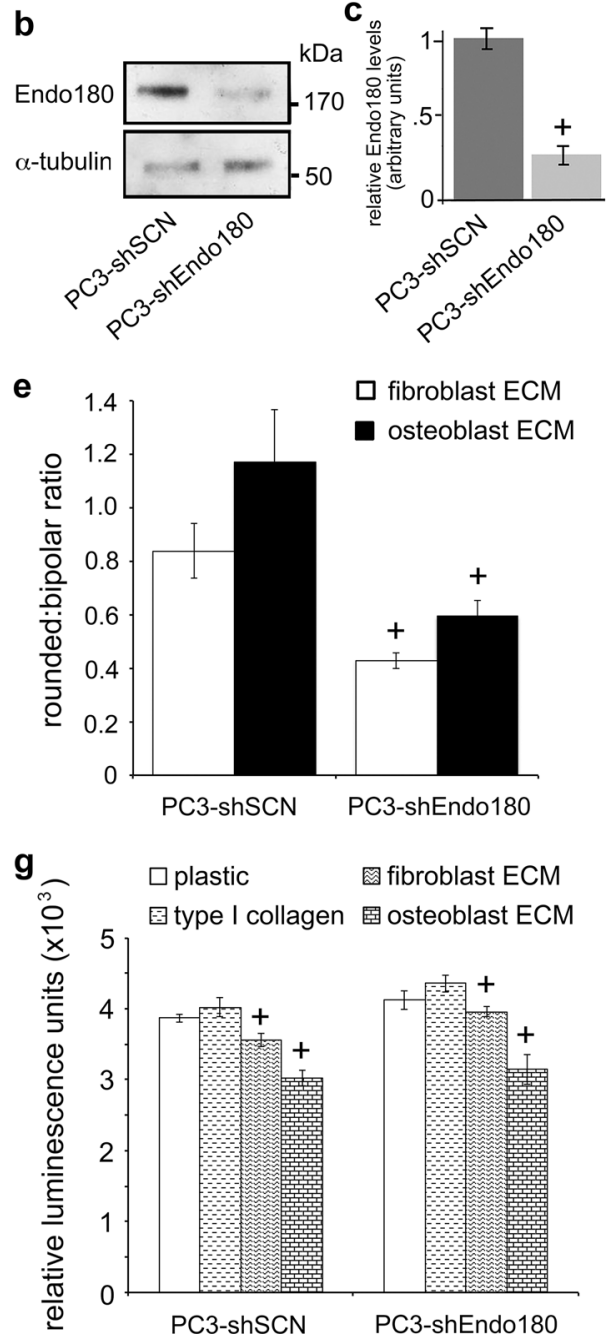

Fig. 5 Silencing Endo180 inhibits metastatic prostate cancer cell migration on human stromal-derived ECM surfaces. a Brightfield and immunofluorescent images of PC3 cells transfected with control shRNA vector containing a targeting Endo180 oligonucleotide sequence (PC3-shEndo180); scale bar $=100 \mu \mathrm{m}$. b, c Immunoblot analysis $(\mathrm{A} 5 / 158 \mathrm{mAb})(\mathbf{b})$ and corresponding denistometric analysis (c) confirming decreased Endo180 expression in PC3-shEndo180 cells compared to control PC3 cells transfected with a vector containing a non-targeting (scrambled) Endo180 oligonucleotide sequence $(\mathrm{PC} 3-\mathrm{shSCN}) \quad(\alpha$-tubulin $=$ loading control). d Stills extracted from Videos 13-16 in Online Resources 13-16 of PC3shSCN and PC3-shEndo180 cells migrating on native ECM generated by human HCA2 dermal fibroblasts (fibroblast ECM) and primary

defective cell detachment from fibroblast-derived ECM and osteoblast-derived ECM, as seen in videos (Online Resources 15 and 16). The adhesion (Fig. 5g) and
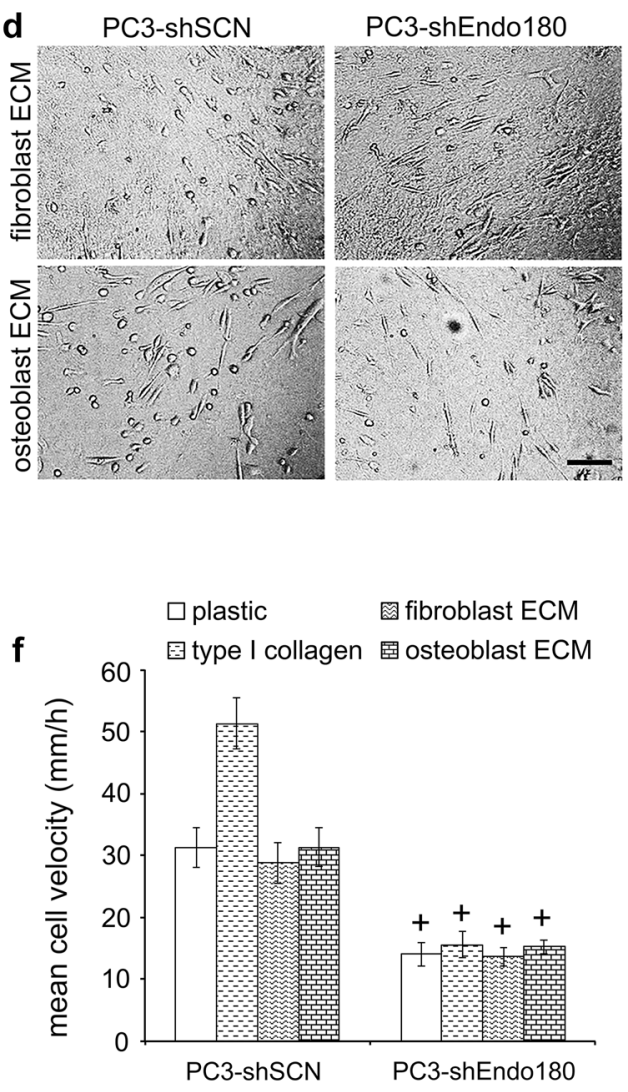

h

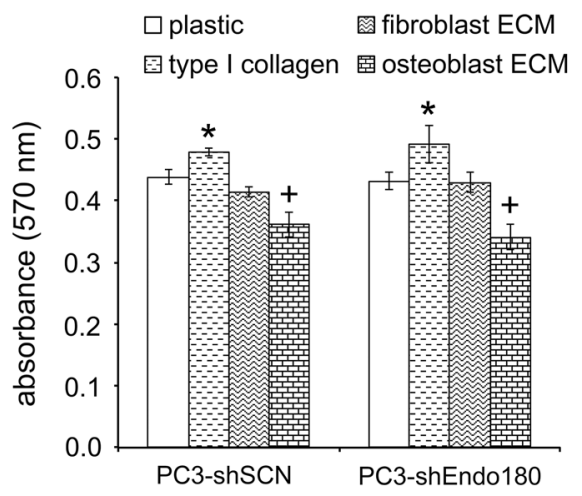

human trabecular bone osteoblasts (osteoblast ECM); scale bar $=50 \mu \mathrm{m}$. e The rounded:bipolar ratios of PC3-shSCN and PC3-shEndo180 cells migrating on fibroblast ECM and osteoblast ECM. f Migration velocities $(\mu \mathrm{m} / \mathrm{h})$ of PC3-shSCN and PC3shEndo180 cells migrating for $24 \mathrm{~h}$ on human fibroblast-derived ECM and human osteoblast-derived ECM; significant decreases in the velocity of PC3-shEndo180 cells compared to pc3-shSCN cells are indicated $\left({ }^{+} \mathrm{p}<0.01\right)$. g, f The adhesion levels at $1 \mathrm{~h}(\mathbf{g})$ and proliferation rates at $48 \mathrm{~h}(\mathbf{h})$ of PC3-shSCN and PC3-shEndo180 cells are shown; significant increases $(* p<0.05)$ and decreases $\left({ }^{+} \mathrm{p}<0.05\right)$ compared to plastic are indicated. $\mathbf{e}-\mathbf{h}$ Average \pm s.d. values for three individual experiments, within which each experimental condition was tested in quadruplicate, are shown

proliferation (Fig. 5h) rates of PC3-shSCN and PC3shEndo180 cells on all substrata were similar to those for parental PC3 cells (Fig. 3b, c). These data confirm that 

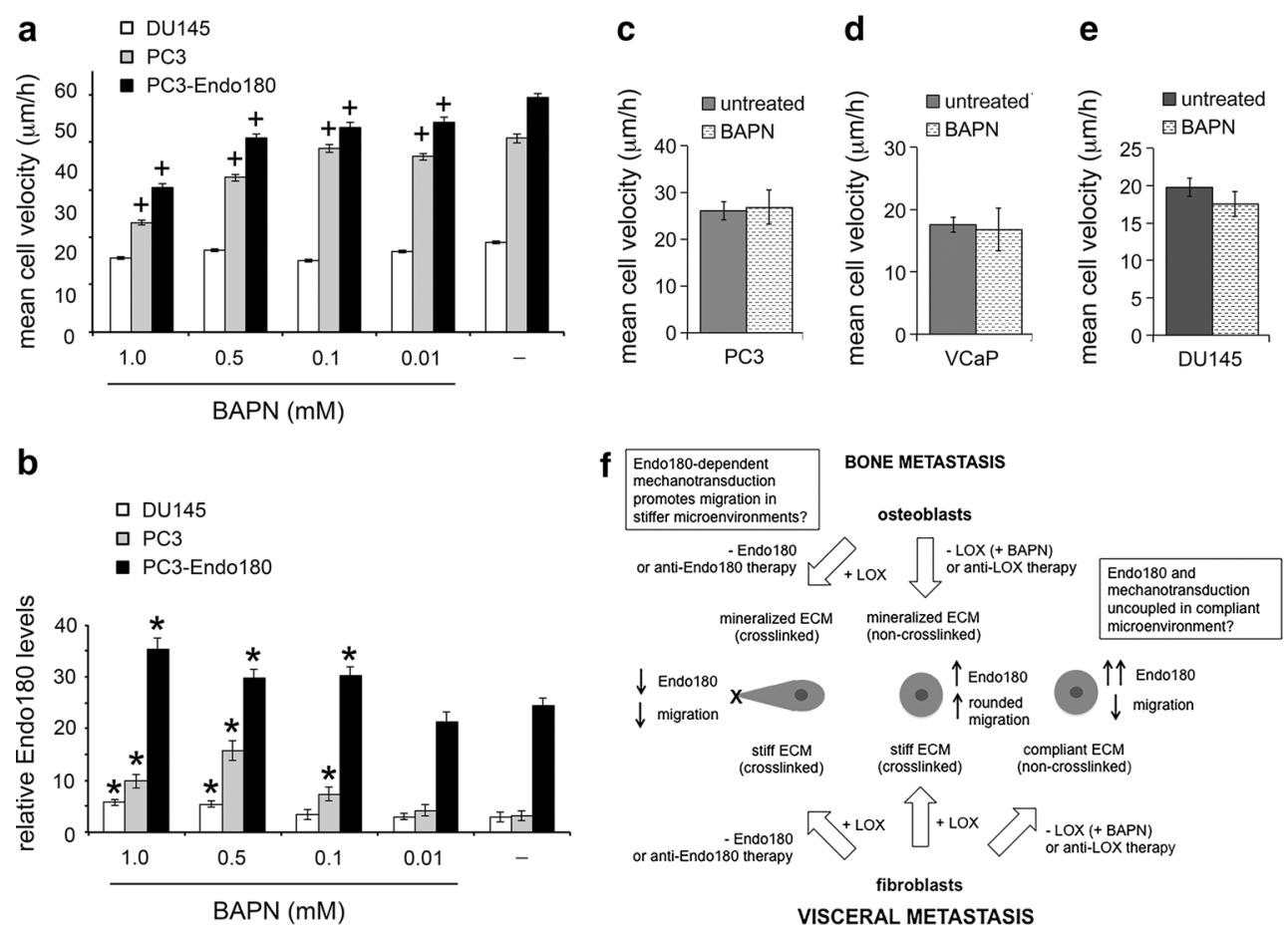

Fig. 6 Endo180 requires LOX-dependent ECM crosslinking of human fibroblast-derived ECM surfaces to promote metastatic prostate cancer cell migration. a Migration velocities $(\mu \mathrm{m} / \mathrm{h})$ of DU145, PC3 and PC3-Endo180 cells for a duration of $24 \mathrm{~h}$ on ECM derived from human HCA2 dermal fibroblasts in the absence $(-)$ or presence of the LOX inhibitor BAPN (0.01-1 mM); significant increases $\left({ }^{*} p<0.05\right)$ and decreases $\left({ }^{+} p<0.05\right)$ compared to cells migrating on control ECM generated by fibroblasts in the absence of BAPN (-) are indicated. b Relative levels of Endo180 expression (integrated fluorescent intensity; $\mathrm{A} 5 / 158 \mathrm{mAb}$ immunostaining) in DU145, PC3 and PC3-Endo180 cells cultured for $24 \mathrm{~h}$ on ECM derived from human HCA2 dermal fibroblasts in the absence $(-)$ or presence of BAPN (0.01-1 mM); significant increases compared to corresponding each corresponding cell line cultured on control fibroblast ECM $(-)$ are indicated $(* \mathrm{p}<0.05)$. c-e Migration velocities $(\mu \mathrm{m} / \mathrm{h})$ of PC3 $(\mathbf{c}), \mathrm{VCaP}(\mathbf{d})$ and DU145 (e) cells migrating for $24 \mathrm{~h}$ on ECM derived from primary human trabecular bone osteoblasts in the absence (-) or presence of the LOX inhibitor BAPN ( $1 \mathrm{mM})$; no significant differences were observed. a-e Average \pm s.d. values for three individual experiments, within which each

Endo180 promotes rounded prostate cancer cell migration on human stromal-cell derived ECM surfaces.

\section{Endo180 cooperates with fibroblast-derived LOX to promote metastatic prostate cancer cell migration}

Given that prostate epithelial cell-associated Endo180 cooperates with AGE-mediated crosslinking of the basement membrane to promote invasiveness [18], we tested the hypothesis that Endo180-dependent metastatic prostate cancer cell migration is promoted by LOX-dependent crosslinking in the stromal ECM associated with bone and visceral tissue. The migratory velocity of parental PC3 and

experimental condition was tested in quadruplicate, are shown. f Schematic diagram that summarizes the findings of this study and their potential therapeutic implications in the context of bone and visceral metastasis. Metastatic prostate cancer cells adopt a rounded mode of cell migration on fibroblast-derived and osteoblast-derived ECM that is associated with increased Endo180 expression. Silencing Endo180 (-Endo180) prevents the translocation of prostate cancer cells on fibroblast-derived ECM and osteoblast-derived ECM due to a detachment defect and the potential loss of Endo180-dependent mechanotransduction. Inhibition of fibroblast-derived LOX activity (-LOX) uncouples Endo180 from its pro-migratory capacity, possibly via loss of its capacity for mechanotransduction in the more compliant non-crosslinked ECM. In contrast the inhibition of osteoblast-derived LOX does not affect prostate cancer cell migration, potentially due to the non-crosslinked mineralized ECM being stiff enough to promote Endo180-dependent mechanotransduction and migration. This model supports the use of anti-LOX therapy for metastasis in visceral tissue and anti-Endo180 therapy for metastasis in bone

PC3-Endo180 cells, but not DU145 cells, was decreased on ECM generated by confluent monolayers of human HCA2 fibroblasts treated with the LOX inhibitor BAPN (0.01-1.0 $\mathrm{mM})$ when compared to their migratory velocity on ECM generated by untreated HCA2 fibroblasts (Fig. 6a). The decrease in PC3 and PC3-Endo180 cell migration on ECM generated by HCA2 fibroblasts treated with BAPN was correlated with an increase in Endo180 expression (Fig. 6b). However, no difference in the migratory velocity of $\mathrm{PC} 3$ cells (Fig. 6c), $\mathrm{VCaP}$ cells (Fig. 6d) and DU145 cells (Fig. 6e) was observed on ECM generated by untreated primary human trabecular bonederived osteoblasts compared to osteoblasts treated with 
1.0 mM BAPN (Fig. 6c). These data suggest that metastatic prostate cancer cell migration involves cooperation between tumor-associated Endo180 and LOX-dependent crosslinking in human fibroblast-derived ECM but not osteoblast-derived ECM.

\section{Discussion}

In this paper we explored the role of two emerging antimetastatic targets involved in collagen matrix homeostasis, Endo180 and LOX, in directing the plasticity of metastatic prostate cancer cells on human ECM surfaces. The in vitro model developed for this purpose involved the introduction of PC3 and VCaP cells originating from metastatic bone lesions [40, 41] and DU145 cells originating from a metastatic lesion in the brain [42] onto human osteoblastderived and fibroblast-derived ECM. VCaP cells adopted a singular and rounded mode of cell migration, and DU145 cells a singular and bipolar mode of cell migration, on fibroblast-derived ECM. This contrasted with their grouped migratory mode under standard culture conditions on tissue culture plastic or a low concentration of non-polymerized reconstituted type I collagen. Moreover, all three prostate cancer cell lines adopted a singular and rounded mode of cell migration on osteoblast-derived ECM (Table 2). These changes in prostate cancer cell migration on human stromal cell-derived ECM closely recapitulate the 'amoeboid-like' mode of migration of tumor cells observed within 3-D lattices formed by high concentrations of polymerized reconstituted type I collagen [11, 43, 44]. These findings suggest that the therapeutic strategies uncovered in these earlier studies may be useful in blocking rounded tumor cell migration and diseemination in MBD and other types of bone cancer.

The intracellular mechanisms of rounded tumor cell migration delineated so far have been centered upon the suppressor and activator signals that regulate RhoA-ROCK and myosin light chain-2 (MLC2)-dependent actinomyosin-based contractility, cytoskeletal remodeling and dynamic cell adhesion events. For example, it has been demonstrated that rounded cell movement can be reversed by Smurf-1, a E3 ubiquitin ligase that targets RhoA for degradation, and PDK1, which antagonizes the RhoE-dependent activation of ROCK [45, 46]. Rounded cell migration is also driven by aberrant activation of RhoA following loss of p53 and p27, the suppression of Rac1 and SOX2, or the expression of EphA2 [43, 47-52]. The interaction between RhoC and FMNL2, Cdc42 and its regulators (DOCK10, RasGRF2) and effectors (N-WASP, PAK2), also promotes rounded cell migration [44, 53-56]; whereas the dephosphorylation of stathmin (a microtubule destabilizing protein), loss of cofilin or depletion of paxillin can block rounded cell migration [57-59].

In this study we have pinpointed the collagen receptor Endo180 as a novel modulator of rounded tumor cell migration in the context of the bone (osteoblast-derived ECM) and visceral tissue (fibroblast-derived ECM) microenvironments. This novel pro-migratory mechanism is consolidated by the upregulation of Endo180 expression by up to $\sim 20$-fold in PC3 cells, $\sim 9$-fold in $\mathrm{VCaP}$ cells and $\sim 7$-fold in DU145 cells on osteoblast-derived ECM compared to control substrata. The possible intracellular cues that can direct this Endo180-associated tumor cell
Table 2 Migratory mode, velocity, adhesion and proliferation rates of human prostate cancer cell lines on human fibroblast and osteoblastderived matrices

\begin{tabular}{llll}
\hline Substratum & PC3 cells & VCaP cells & DU145 cells \\
\hline Tissue culture plastic & Singular, bipolar & Grouped, epithelioid & Grouped, epithelioid \\
Commercial type I collagen & Singular, Bipolar & Singular, bipolar & Grouped, epithelioid \\
& $\Uparrow$ Velocity & $\Leftrightarrow$ Velocity & $\Leftrightarrow$ Velocity \\
& $\Leftrightarrow$ Adhesion & $\Leftrightarrow$ Adhesion & $\Downarrow$ Adhesion \\
& $\Leftrightarrow$ Proliferation & $\Leftrightarrow$ Proliferation & $\Downarrow$ Proliferation \\
Fibroblast ECM & Singular, mixed & Singular, rounded & singular, bipolar \\
& $\Leftrightarrow$ Velocity & $\Downarrow$ Velocity & $\Uparrow$ Velocity \\
& $\Downarrow$ Adhesion & $\Leftrightarrow$ Adhesion & $\Leftrightarrow$ Adhesion \\
& $\Leftrightarrow$ Proliferation & $\Downarrow$ Proliferation & $\Downarrow$ Proliferation \\
Osteoblast ECM & Singular, rounded & Singular, rounded & Singular, rounded \\
& $\Uparrow$ Velocity & $\Downarrow$ Velocity & $\Uparrow$ Velocity \\
& $\Downarrow$ Adhesion & $\Leftrightarrow$ Adhesion & $\Downarrow$ Adhesion \\
& $\Downarrow$ Proliferation & $\Downarrow$ Proliferation & $\Downarrow$ Proliferation \\
\hline
\end{tabular}

Definition of migratory modes: grouped ( $>80 \%$ of cells migrate as part of an epithelioid cluster); bipolar (rounded/bipolar ratio $<1.0$ ); rounded (rounded/bipolar ratio $>1.0$ ); mixed (rounded/bipolar ratio $=1.0$ ). All changes shown are in comparison to plastic

ECM extracellular matrix 
plasticity include Cdc42 and Rac1 and the Rho-ROCKMLC2 pathway, which are activated by the spatiotemporal localization of the Endo180 receptor to the plasma membrane or constitutively recycling endosomes [18, 19, 26]. Interestingly two key Endo180 interaction partners, CD147 and urokinase-type plasminogen activator receptor (uPAR) $[17,26]$, have been identified as regulators of rounded cell migration [60, 61]. CD147-annexin II complex acts as a molecular switch that directs rounded-to-bipolar transitions during cell migration. It is feasible that Endo180-CD147 complex [17] also plays a modulatory role in tumor cell plasticity on human stromal cell-derived ECM. In this respect we hypothesize that Endo180-CD147 complex disruption can promote rounded tumor cell migration and Endo180-CD147 complex formation can uncouple Endo180 and the intracellular machinery that drives rounded tumor cell migration. It is also possible that the integrin-dependent actomyosin contractile signals generated at the pseudo-uropod-like structure at the rear of spheroidal cells during rounded cell migration [14] involves the spatiotemporal activation of Rho-ROCK-MLC2-based contractile signals by Endo180-containing endosomes. This prediction is supported by the fact that de-adhesion of the uropod at the rear of MG63 osteosarcoma cells requires the Endo180-Rho-ROCK-MLC2 signalling axis [19]. It will also be interesting to consider if the strong Endo180 clusters in PC3-Endo180 cells on osteoblast-derived ECM contribute to their rounded mode of migration.

The requirement of LOX-dependent ECM crosslinking and stiffness for Endo180-dependent tumor cell migration is aligned with the finding that non-enzymatic crosslinking of basement membrane matrix coupled with Endo180-dependent mechanotransduction triggers epithelial cell invasiveness [18]. When considering the design of Endo180 based anti-metastatic therapies it will be important to fully explore the relative contributions of the two functional C-type lectin domains (CTLDs) in the receptor, CTLD2 and CTLD4, to the migratory behavior of metastatic prostate cancer cells in the context of human ECM lattices that have different levels of stiffness. Our findings indicate that where the ECM is more compliant Endo180 and CD147 form a molecular complex that involves CTLD4 and suppresses epithelial cell invasiveness [17]. This suggests that in compliant tissue it would not be desirable to target CTLD4. On the flipside, blockade of CTLD2-dependent mechanotransduction, which can inhibit the epithelial cell invasiveness induced by non-enzymatic crosslinking and increased stiffness of the basement membrane [18], could be used to prevent rounded tumor cell migration in stiff visceral tissue and bone.

In contrast to the finding that Endo180 is uncoupled from its ability to promote tumor cell migration on compliant (non-crosslinked) fibroblast-derived ECM, no differences were observed in the migration of tumor cells on non-crosslinked versus crosslinked osteoblast-derived ECM. Although our findings suggest that osteoblastderived LOX does not affect metastatic prostate cancer cell migration, tumor-derived LOX participates in the progression of osteolytic bone metastasis in breast cancer [38]. In the current study we did not consider the cooperative roles of tumor-derived LOX and Endo180 in driving the plasticity of tumor cell movement on human fibroblastderived and osteoblast-derived ECM surfaces. Consideration of this possibility together with the evaluation of Endo180 and LOX as targets in pre-clinical models of osteolytic bone tumors induced by PC 3 and DU145 cells [62-64] and predominantly osteosclerotic tumors induced by $\mathrm{VCaP}$ cells [65] will be prioritised in our future work. The finding that LOX-dependent crosslinking of human fibroblast-derived ECM is required to promote tumor cell migration, indicates that anti-Endo180 and/or anti-LOX therapy is a feasible therapeutic option for the treatment of visceral tumors surrounded by a stiffened stroma (Fig. $6 \mathrm{f}$ ).

The findings of this study provide new insight into the consequences of Endo180 upregulation on prostate tumor cells in contact with osteoblasts [4], positive Endo180 immunostaining of tumor cell foci in metastatic bone lesions [4] and raised levels of soluble Endo180 in the serum of patients with osseous and/or visceral metastases [31]. The heterotypic interaction of osteoblasts with prostate cancer cells was previously shown to suppress Endo180 expression in the osteoblasts resulting in decreased mineralized collagen production [4]. Here we have demonstrated that osteoblast-derived ECM increases Endo180 expression in tumor cells to drive their transition to a rounded mode of migration. Therapeutic strategies that can suppress Endo180 function in metastatic disease (Fig. 6f), combined with the development of Endo180-targeted diagnostics, could provide the opportunity to make a major advance in the personalized treatment of men with Endo180-positive prostate cancer who are at risk of, or have progressed towards, the development of Endo180-driven bone metastasis [17, 18].

Acknowledgments We thank Professor Justin Cobb (Imperial College London) for providing human trabecular bone, Professor David Kipling (Cardiff University) for HCA2-hTERT human fibroblasts and Professor Daniel Aeschlimann for the HCA2 matrix generation protocol. We thank Alexandra Glymond and Imogen S Broadbent (University of Hull) for their assistance with data analysis. The Rosetrees Trust (Grants JS16/M59, M40/M41), The Association of International Cancer Research (now Worldwide Cancer Research) (Grant 08-0803) and The Prostate Cancer Charity (now Prostate Cancer UK) (Grant 110632) funded this work. NS was funded by a British Society of Cell Biology summer studentship.

\section{Compliance with ethical standards}

Conflict of interest The authors declare that they do not have any competing or financial interests. 
Ethical standards The use of post-operative human trabecular bone from patients undergoing hip replacement surgery was granted approval by Research Ethics Committee of Imperial College NHS Healthcare Trust (reference number: 10/H0711/19) who specifically approved use in prostate cancer research and all persons gave informed consent prior to inclusion in the study. Therefore this research was performed in accordance with the ethical standards laid down in the 1964 Declaration of Helsinki and its later amendments.

Open Access This article is distributed under the terms of the Creative Commons Attribution 4.0 International License (http://crea tivecommons.org/licenses/by/4.0/), which permits unrestricted use, distribution, and reproduction in any medium, provided you give appropriate credit to the original author(s) and the source, provide a link to the Creative Commons license, and indicate if changes were made.

\section{References}

1. Sturge J, Caley MP, Waxman J (2011) Bone metastasis in prostate cancer: emerging therapeutic strategies. Nat Rev Clin Oncol 8(6):357-368. doi:10.1038/nrclinonc.2011.67

2. Reichert JC, Quent VMC, Burke LJ, Stansfield SH, Clements JA, Hutmacher DW (2010) Mineralized human primary osteoblast matrices as a model system to analyse interactions of prostate cancer cells with the bone microenvironment. Biomaterials 31(31):7928-7936. doi:10.1016/j.biomaterials.2010.06.055

3. Hesami P, Holzapfel BM, Taubenberger A, Roudier M, Fazli L, Sieh S, Thibaudeau L, Gregory LS, Hutmacher DW, Clements JA (2014) A humanized tissue-engineered in vivo model to dissect interactions between human prostate cancer cells and human bone. Clin Exp Metastasis. doi:10.1007/s10585-014-9638-5

4. Caley MP, Kogianni G, Adamarek A, Gronau JH, RodriguezTeja M, Fonseca AV, Mauri F, Sandison A, Rhim JS, Palmieri C, Cobb JP, Waxman J, Sturge J (2012) TGFbeta1-Endo180-dependent collagen deposition is dysregulated at the tumour-stromal interface in bone metastasis. J Pathol 226(5):775-783. doi:10.1002/path.3958

5. Berning M, Pratzel-Wunder S, Bickenbach JR, Boukamp P (2015) Three-dimensional in vitro skin and skin cancer models based on human fibroblast-derived matrix. Tissue Eng Part C Methods. doi:10.1089/ten.TEC.2014.0698

6. Serebriiskii I, Castello-Cros R, Lamb A, Golemis EA, Cukierman E (2008) Fibroblast-derived 3D matrix differentially regulates the growth and drug-responsiveness of human cancer cells. Matrix Biol 27(6):573-585. doi:10.1016/j.matbio.2008.02.008

7. Friedl P, Alexander S (2011) Cancer invasion and the microenvironment: plasticity and reciprocity. Cell 147(5):992-1009. doi:10.1016/j.cell.2011.11.016

8. Friedl P, Sahai E, Weiss S, Yamada KM (2012) New dimensions in cell migration. Nat Rev Mol Cell Biol 13(11):743-747. doi:10. 1038/nrm3459

9. Friedl P, Wolf K (2003) Tumour-cell invasion and migration: diversity and escape mechanisms. Nat Rev Cancer 3(5):362-374

10. Brabek J, Mierke CT, Rosel D, Vesely P, Fabry B (2010) The role of the tissue microenvironment in the regulation of cancer cell motility and invasion. Cell Commun Signal 8:22. doi:10.1186/ 1478-811X-8-22

11. Sanz-Moreno V, Gaggioli C, Yeo M, Albrengues J, Wallberg F, Viros A, Hooper S, Mitter R, Feral CC, Cook M, Larkin J, Marais R, Meneguzzi G, Sahai E, Marshall CJ (2011) ROCK and JAK1 signaling cooperate to control actomyosin contractility in tumor cells and stroma. Cancer Cell 20(2):229-245. doi:10.1016/j.ccr. 2011.06.018

12. Wolf $\mathrm{K}$, Mazo I, Leung $\mathrm{H}$, Engelke $\mathrm{K}$, von Andrian UH, Deryugina EI, Strongin AY, Brocker EB, Friedl P (2003) Compensation mechanism in tumor cell migration: mesenchymalamoeboid transition after blocking of pericellular proteolysis. J Cell Biol 160(2):267-277. doi:10.1083/jcb.200209006

13. Carragher NO, Walker SM, Scott Carragher LA, Harris F, Sawyer TK, Brunton VG, Ozanne BW, Frame MC (2006) Calpain 2 and Src dependence distinguishes mesenchymal and amoeboid modes of tumour cell invasion: a link to integrin function. Oncogene 25(42):5726-5740. doi:10.1038/sj.onc.1209582

14. Poincloux R, Collin O, Lizarraga F, Romao M, Debray M, Piel M, Chavrier P (2011) Contractility of the cell rear drives invasion of breast tumor cells in 3D Matrigel. Proc Natl Acad Sci USA 108(5):1943-1948. doi:10.1073/pnas.1010396108

15. Lorentzen A, Bamber J, Sadok A, Elson-Schwab I, Marshall CJ (2011) An ezrin-rich, rigid uropod-like structure directs movement of amoeboid blebbing cells. J Cell Sci 124(8):1256-1267. doi: $10.1242 /$ jcs.074849

16. Wyckoff JB, Pinner SE, Gschmeissner S, Condeelis JS, Sahai E (2006) ROCK-and myosin-dependent matrix deformation enables protease-independent tumor-cell invasion in vivo. Curr Biol 16(15):1515-1523. doi:10.1016/j.cub.2006.05.065

17. Rodriguez-Teja M, Gronau JH, Minamidate A, Darby S, Gaughan L, Robson C, Mauri F, Waxman J, Sturge J (2015) Survival outcome and EMT suppression mediated by a lectin domain interaction of Endo180 and CD147. Mol Cancer Res 13(3):538-547. doi:10.1158/1541-7786.MCR-14-0344-T

18. Rodriguez-Teja M, Gronau JH, Breit C, Zhang YZ, Minamidate A, Caley MP, McCarthy A, Cox TR, Erler JT, Gaughan L, Darby S, Robson C, Mauri F, Waxman J, Sturge J (2015) AGE-modified basement membrane cooperates with Endo180 to promote epithelial cell invasiveness and decrease prostate cancer survival. J Pathol 235(4):581-592. doi:10.1002/path.4485

19. Sturge J, Wienke D, Isacke CM (2006) Endosomes generate localized Rho-ROCK-MLC2-based contractile signals via Endo180 to promote adhesion disassembly. J Cell Biol 175(2):337-347. doi:10.1083/jcb.200602125

20. East L, McCarthy A, Wienke D, Sturge J, Ashworth A, Isacke CM (2003) A targeted deletion in the endocytic receptor gene Endo180 results in a defect in collagen uptake. EMBO Rep 4(7):710-716. doi:10.1038/sj.embor.embor882

21. Engelholm LH, List K, Netzel-Arnett S, Cukierman E, Mitola DJ, Aaronson H, Kjoller L, Larsen JK, Yamada KM, Strickland DK, Holmbeck K, Dano K, Birkedal-Hansen H, Behrendt N, Bugge TH (2003) uPARAP/Endo180 is essential for cellular uptake of collagen and promotes fibroblast collagen adhesion. J Cell Biol 160(7):1009-1015. doi:10.1083/jcb.200211091

22. Honardoust HA, Jiang G, Koivisto L, Wienke D, Isacke CM, Larjava H, Hakkinen L (2006) Expression of Endo180 is spatially and temporally regulated during wound healing. Histopathology 49(6):634-648. doi:10.1111/j.1365-2559.2006.02559.x

23. Ikenaga N, Ohuchida K, Mizumoto K, Akagawa S, Fujiwara K, Eguchi D, Kozono S, Ohtsuka T, Takahata S, Tanaka M (2012) Pancreatic cancer cells enhance the ability of collagen internalization during epithelial-mesenchymal transition. PLoS ONE 7(7):e40434. doi:10.1371/journal.pone.0040434

24. Messaritou G, East L, Roghi C, Isacke CM, Yarwood H (2009) Membrane type-1 matrix metalloproteinase activity is regulated by the endocytic collagen receptor Endo180. J Cell Sci 122(22):4042-4048. doi:10.1242/jcs.044305

25. Mousavi SA, Sato M, Sporstol M, Smedsrod B, Berg T, Kojima N, Senoo H (2005) Uptake of denatured collagen into hepatic stellate cells: evidence for the involvement of urokinase 
plasminogen activator receptor-associated protein/Endo180. Biochem J 387(1):39-46. doi:10.1042/BJ20040966

26. Sturge J, Wienke D, East L, Jones GE, Isacke CM (2003) GPIanchored uPAR requires Endo180 for rapid directional sensing during chemotaxis. J Cell Biol 162(5):789-794. doi:10.1083/jcb. 200302124

27. Takahashi S, Yamada-Okabe H, Hamada K, Ohta S, Kawase T, Yoshida K, Toda M (2011) Downregulation of uPARAP mediates cytoskeletal rearrangements and decreases invasion and migration properties in glioma cells. J Neurooncol 103(2):267276. doi:10.1007/s11060-010-0398-z

28. Jensen PR, Andersen TL, Pennypacker BL, le Duong T, Engelholm LH, Delaisse JM (2014) A supra-cellular model for coupling of bone resorption to formation during remodeling: lessons from two bone resorption inhibitors affecting bone formation differently. Biochem Biophys Res Commun 443(2):694-699. doi:10.1016/j.bbrc.2013.12.036

29. Curino AC, Engelholm LH, Yamada SS, Holmbeck K, Lund LR, Molinolo AA, Behrendt N, Nielsen BS, Bugge TH (2005) Intracellular collagen degradation mediated by uPARAP/Endo180 is a major pathway of extracellular matrix turnover during malignancy. J Cell Biol 169(6):977-985. doi:10.1083/jcb.2004 11153

30. Huijbers IJ, Iravani M, Popov S, Robertson D, Al-Sarraj S, Jones C, Isacke CM (2010) A role for fibrillar collagen deposition and the collagen internalization receptor Endo180 in glioma invasion. PLoS ONE 5(3):e9808. doi:10.1371/journal.pone.0009808

31. Palmieri C, Caley MP, Purshouse K, Fonseca AV, RodriguezTeja M, Kogianni G, Woodley L, Odendaal J, Elliott K, Waxman J, Sturge J (2013) Endo180 modulation by bisphosphonates and diagnostic accuracy in metastatic breast cancer. $\mathrm{Br} \mathrm{J}$ Cancer 108(1):163-169. doi:10.1038/bjc.2012.540

32. Kagan HM, Li W (2003) Lysyl oxidase: properties, specificity, and biological roles inside and outside of the cell. J Cell Biochem 88(4):660-672. doi:10.1002/jcb.10413

33. Lucero H, Kagan H (2006) Lysyl oxidase: an oxidative enzyme and effector of cell function. Cell Mol Life Sci 63(19):2304-2316. doi:10.1007/s00018-006-6149-9

34. Erler JT, Bennewith KL, Nicolau M, Dornhofer N, Kong C, Le QT, Chi JT, Jeffrey SS, Giaccia AJ (2006) Lysyl oxidase is essential for hypoxia-induced metastasis. Nature 440(7088): 1222-1226. doi:10.1038/nature04695

35. Erler JT, Bennewith KL, Cox TR, Lang G, Bird D, Koong A, Le QT, Giaccia AJ (2009) Hypoxia-induced lysyl oxidase is a critical mediator of bone marrow cell recruitment to form the premetastatic niche. Cancer Cell 15(1):35-44. doi:10.1016/j.ccr. 2008.11.012

36. Baker AM, Bird D, Lang G, Cox TR, Erler JT (2013) Lysyl oxidase enzymatic function increases stiffness to drive colorectal cancer progression through FAK. Oncogene 32(14):1863-1868. doi:10.1038/onc.2012.202

37. Levental KR, Yu H, Kass L, Lakins JN, Egeblad M, Erler JT, Fong SF, Csiszar K, Giaccia A, Weninger W, Yamauchi M, Gasser DL, Weaver VM (2009) Matrix crosslinking forces tumor progression by enhancing integrin signaling. Cell 139(5):891-906. doi:10.1016/j.cell.2009.10.027

38. Cox TR, Rumney RM, Schoof EM, Perryman L, Hoye AM, Agrawal A, Bird D, Latif NA, Forrest H, Evans HR, Huggins ID, Lang G, Linding R, Gartland A, Erler JT (2015) The hypoxic cancer secretome induces pre-metastatic bone lesions through lysyl oxidase. Nature 522(7554):106-110. doi:10.1038/nature14 492

39. Wienke D, MacFadyen JR, Isacke CM (2003) Identification and characterization of the endocytic transmembrane glycoprotein Endo180 as a novel collagen receptor. Mol Biol Cell 14(9):3592-3604. doi:10.1091/mbc.E02-12-0814
40. Kaighn ME, Narayan KS, Ohnuki Y, Lechner JF, Jones LW (1979) Establishment and characterization of a human prostatic carcinoma cell line (PC-3). Invest Urol 17(1):16-23

41. Korenchuk S, Lehr JE, MClean L, Lee YG, Whitney S, Vessella R, Lin DL, Pienta KJ (2001) VCaP, a cell-based model system of human prostate cancer. Vivo 15(2):163-168

42. Stone KR, Mickey DD, Wunderli H, Mickey GH, Paulson DF (1978) Isolation of a human prostate carcinoma cell line (DU145). Int J Cancer 21(3):274-281

43. Sanz-Moreno V, Gadea G, Ahn J, Paterson H, Marra P, Pinner S, Sahai E, Marshall CJ (2008) Rac activation and inactivation control plasticity of tumor cell movement. Cell 135(3):510-523. doi:10.1016/j.cell.2008.09.043

44. Gadea G, Sanz-Moreno V, Self A, Godi A, Marshall CJ (2008) DOCK10-mediated Cdc42 activation is necessary for amoeboid invasion of melanoma cells. Curr Biol 18(19):1456-1465. doi:10. 1016/j.cub.2008.08.053

45. Sahai E, Garcia-Medina R, Pouyssegur J, Vial E (2007) Smurf1 regulates tumor cell plasticity and motility through degradation of RhoA leading to localized inhibition of contractility. J Cell Biol 176(1):35-42. doi:10.1083/jcb.200605135

46. Pinner S, Sahai E (2008) PDK1 regulates cancer cell motility by antagonising inhibition of ROCK1 by RhoE. Nat Cell Biol 10(2):127-137. doi:10.1038/ncb1675

47. Oppel F, Muller N, Schackert G, Hendruschk S, Martin D, Geiger KD, Temme A (2011) SOX2-RNAi attenuates S-phase entry and induces RhoA-dependent switch to protease-independent amoeboid migration in human glioma cells. Mol Cancer 10:137. doi:10.1186/1476-4598-10-137

48. Berton S, Belletti B, Wolf K, Canzonieri V, Lovat F, Vecchione A, Colombatti A, Friedl P, Baldassarre G (2009) The tumor suppressor functions of $\mathrm{p} 27(\mathrm{kip} 1)$ include control of the mesenchymal/amoeboid transition. Mol Cell Biol 29(18):5031-5045. doi:10.1128/MCB.00144-09

49. Gadea G, de Toledo M, Anguille C, Roux P (2007) Loss of p53 promotes RhoA-ROCK-dependent cell migration and invasion in 3D matrices. J Cell Biol 178(1):23-30. doi:10.1083/jcb. 200701120

50. Yamazaki D, Kurisu S, Takenawa T (2009) Involvement of Rac and Rho signaling in cancer cell motility in 3D substrates. Oncogene 28(13):1570-1583. doi:10.1038/onc.2009.2

51. Parri M, Taddei ML, Bianchini F, Calorini L, Chiarugi P (2009) EphA2 reexpression prompts invasion of melanoma cells shifting from mesenchymal to amoeboid-like motility style. Cancer Res 69(5):2072-2081. doi:10.1158/0008-5472.CAN-08-1845

52. Taddei ML, Parri M, Angelucci A, Bianchini F, Marconi C, Giannoni E, Raugei G, Bologna M, Calorini L, Chiarugi P (2011) EphA2 induces metastatic growth regulating amoeboid motility and clonogenic potential in prostate carcinoma cells. Mol Cancer Res 9(2):149-160. doi:10.1158/1541-7786.MCR-10-0298

53. Kitzing TM, Wang Y, Pertz O, Copeland JW, Grosse R (2010) Formin-like 2 drives amoeboid invasive cell motility downstream of RhoC. Oncogene 29(16):2441-2448. doi:10.1038/onc.2009. 515

54. Calvo F, Sanz-Moreno V, Agudo-Ibanez L, Wallberg F, Sahai E, Marshall CJ, Crespo P (2011) RasGRF suppresses Cdc42-mediated tumour cell movement, cytoskeletal dynamics and transformation. Nat Cell Biol 13(7):819-826. doi:10.1038/ncb2271

55. Mishima T, Naotsuka M, Horita Y, Sato M, Ohashi K, Mizuno K (2010) LIM-kinase is critical for the mesenchymal-to-amoeboid cell morphological transition in 3D matrices. Biochem Biophys Res Commun 392(4):577-581. doi:10.1016/j.bbrc.2010.01.075

56. Elson-Schwab I, Lorentzen A, Marshall CJ (2010) MicroRNA200 family members differentially regulate morphological plasticity and mode of melanoma cell invasion. PLoS ONE. doi:10. 1371/journal.pone. 0013176 
57. Sidani M, Wessels D, Mouneimne G, Ghosh M, Goswami S, Sarmiento C, Wang W, Kuhl S, El-Sibai M, Backer JM, Eddy R, Soll D, Condeelis J (2007) Cofilin determines the migration behavior and turning frequency of metastatic cancer cells. J Cell Biol 179(4):777-791. doi:10.1083/jcb.200707009

58. Belletti B, Nicoloso MS, Schiappacassi M, Berton S, Lovat F, Wolf K, Canzonieri V, D'Andrea S, Zucchetto A, Friedl P, Colombatti A, Baldassarre G (2008) Stathmin activity influences sarcoma cell shape, motility, and metastatic potential. Mol Biol Cell 19(5):2003-2013. doi:10.1091/mbc.E07-09-0894

59. Deakin NO, Turner CE (2011) Distinct roles for paxillin and Hic5 in regulating breast cancer cell morphology, invasion, and metastasis. Mol Biol Cell 22(3):327-341. doi:10.1091/mbc.E1009-0790

60. Margheri F, Luciani C, Taddei ML, Giannoni E, Laurenzana A, Biagioni A, Chilla A, Chiarugi P, Fibbi G, Del Rosso M (2014) The receptor for urokinase-plasminogen activator (uPAR) controls plasticity of cancer cell movement in mesenchymal and amoeboid migration style. Oncotarget 5(6):1538-1553

61. Zhao P, Zhang W, Wang SJ, Yu XL, Tang J, Huang W, Li Y, Cui HY, Guo YS, Tavernier J, Zhang SH, Jiang JL, Chen ZN (2011) HAb18G/CD147 promotes cell motility by regulating annexin IIactivated RhoA and Rac1 signaling pathways in hepatocellular carcinoma cells. Hepatology 54(6):2012-2024. doi:10.1002/hep. 24592

62. Nemeth JA, Harb JF, Barroso U Jr, He Z, Grignon DJ, Cher ML (1999) Severe combined immunodeficient-hu model of human prostate cancer metastasis to human bone. Cancer Res 59(8):1987-1993

63. Akech J, Wixted JJ, Bedard K, van der Deen M, Hussain S, Guise TA, van Wijnen AJ, Stein JL, Languino LR, Altieri DC, Pratap J, Keller E, Stein GS, Lian JB (2009) Runx2 association with progression of prostate cancer in patients: mechanisms mediating bone osteolysis and osteoblastic metastatic lesions. Oncogene 29(6):811-821. doi:10.1038/onc.2009.389

64. Lee Y, Schwarz E, Davies M, Jo M, Gates J, Wu J, Zhang X, Lieberman JR (2003) Differences in the cytokine profiles associated with prostate cancer cell induced osteoblastic and osteolytic lesions in bone. J Orthopaed Res 21(1):62-72

65. Graham TJ, Box G, Tunariu N, Crespo M, Spinks TJ, Miranda S, Attard G, de Bono J, Eccles SA, Davies FE, Robinson SP (2014) Preclinical evaluation of imaging biomarkers for prostate cancer bone metastasis and response to cabozantinib. J Nat Cancer Inst 106(4):dju033. doi:10.1093/jnci/dju033 